\title{
特種製紙(株)三島工場
}

\section{-Mishima Mill, Tokushu Paper Mfg, Co., Ltd.-}

\section{1 はしめに}

当社は静岡県駿東郡長泉町（新幹線の三島駅より夕 クシー5 分）に本社及ひ総合技術研究所と三島工場を， 岐阜市上川手に岐阜工場を有し, 両工場共に多品種少 量生産により五千数百種類の特殊紙を生産している。 長泉町は爱鹰山の南麓て富士山と箱根とを逆三角形の 底匀とする頂点に位置し, 富士山系の豊富な水脈の下 梳にあり, 年間水温か一定て $15^{\circ} \mathrm{C}$ の良好な水質と豊 かな水量の恩恵に俗している。三島工場の誕生は大正 15 年 11 月 21 日て, 当時その殆んとを輸入に依存し ていた特殊紙の国産化を願って, 元内閣印刷局抄紙部 長佐伯勝太郎博士を社長に迎えて発足した。

\section{2 工場の概要 (表 1)}

当工場は JRの東海道線と御殿場線に隣接し, 総合 技術研究所も含め 12 万 6 千 $\mathrm{m}^{2}$ の敷地内にあり, 組 織は 6 部制て全從業員 360 名, 4 直 3 交替体制てある。 年間生産量は特殊情報用紙, 商業美術印刷用紙, 工業 用紙, 耐水印刷用紙, 合成皮革紙, その他て, 何れも 小型の 9 台の抄紙機と 6 台の加工機による多品種少量 生産て年間約 6 万屯てある。一般量産紙とは生産規模, 方式, 設備, 品質等コンセプトか全く異なり, 従って 需要量も量産紙に比し極端に少なく設備投資競争はな いか, 一方商品のライフサイクルか短く新製品の開発 競争か嬂列てある。それゆ之品質に就ての要求は橄し く, 一旦クレームか発生するとその対応は多大の時間

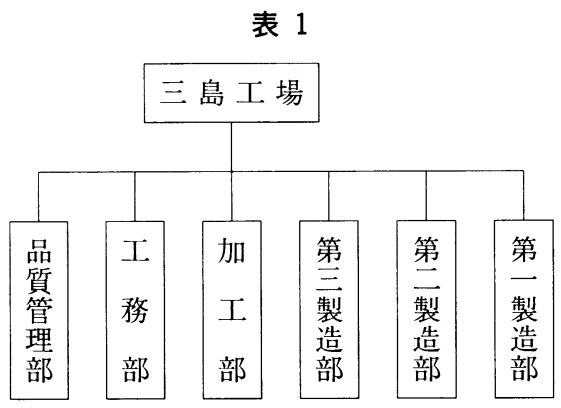

と出費を伴うのて, 工程保証をモ,トーとして TQC 活動を全社に導入して精焦している。

\section{3 設備の概要}

\section{1 原質部門}

（1）原料受入設備 (写真 1-a，1-b，1-c，1-d) 当社はパルプ製造設備かなくその全量を外部より購 入しており, 従って一度乾燥履歴を経たパルプを使用 するのて, 紙の品質上最大の問題点の一つてある。寸 法安定性や不透明度の向上に寄与すると共に, 抄造銘 柄に対して最適のパルプをその都度必要量宛使用する 事か可能てある。搬入したパルプは当社か専業メ一カ 一と共同開発したパルプヘール自動解相機により, 自 動的にワイヤーを切断して污染したへールを除去する と共に, 夫々のパルパーに輸送する。パルプとしては, 多種類の木材パルプや特殊パルプやその他リサイクル 原料等を使用しており，その荷姿やサイスも千差万別 てきめ細かい対応をしている。

(2) 調成設備 (写真 2，3）

量産紙とは異なり, 多品種小口, 卜生産て頻繁な色 替えや調成条件の変更に対応する为に，パルパーへの 連続投入か不可能て八, 千式か基本となり, 多品種の パルプを抄造銘柄に応してそれそれ選択してへール単 位及ひ枚葉単位て投入する。あわせて必要とされる薬 品等も投入するか，之等の作業は皆コンピューターに より自動化して, 腰痛作業を駆遂して生産性の向上を はたしている。吒解機は各抄紙機の特性により，各種 のヒーターやレフアイナーを組合せて使用している。

\section{2 抄紙部門（表 2)（写真 4)}

三島工場には表 2 に示す如く現在 7 台の長網抄紙機 と 2 台の円網抄紙機かあり, 設置年度は古いか適時に 改善工事を行って, 最高の品質を保証可能な態勢をと っている。安定した品質の保証には設備の安定した運 転か先决て, 設備保全技術のレヘルア,プに努力して いる。保全体制としては過去の BM (事後保全), $\mathrm{PM}$ (予防保全) を経て, 新規の設備診断技術による PdM (予知保全) 体制を導入している。抄紙機の各 


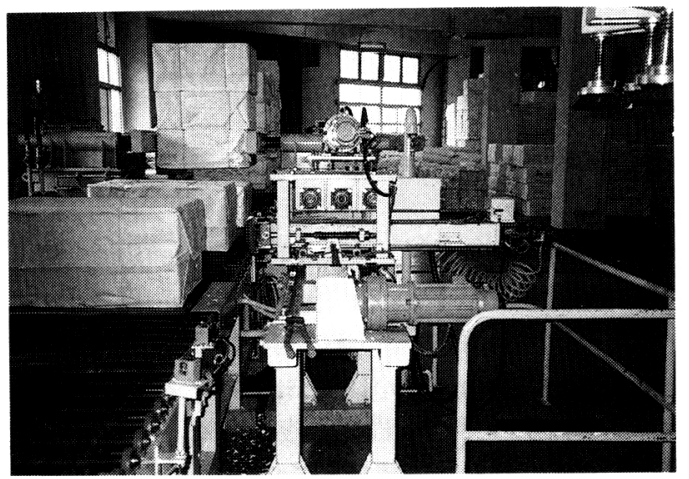

写真 1-a パルプベール自動開梱機全景

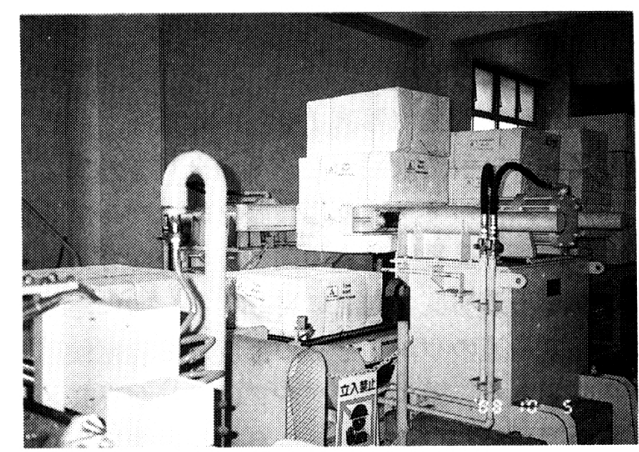

写真 1-b （同上）段ばらし装置

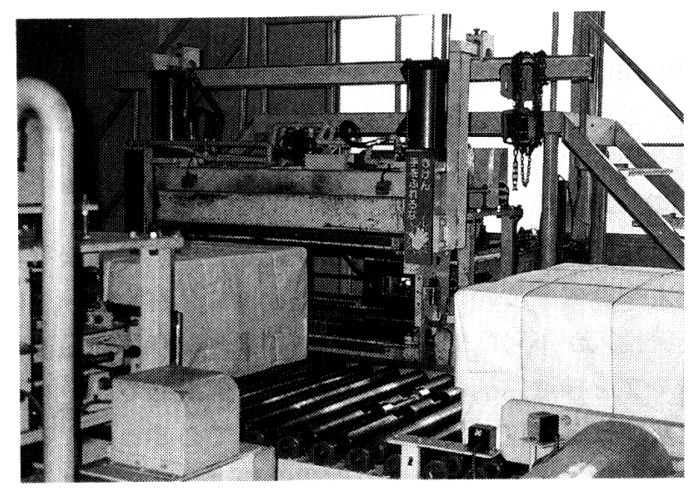

写真 1-c (同上) ワイヤー切断装置

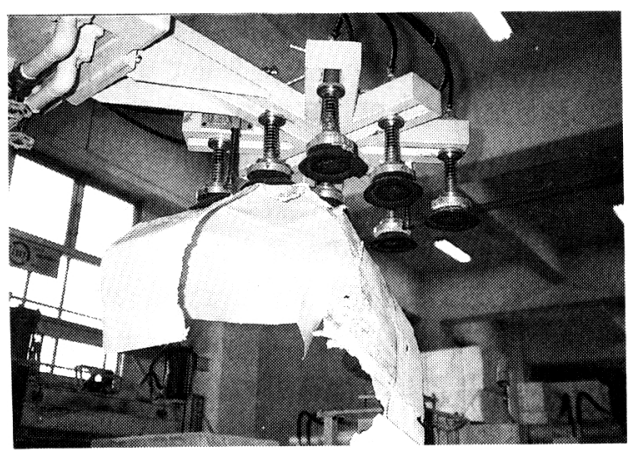

写真 1-d（同上）ベール除去装置

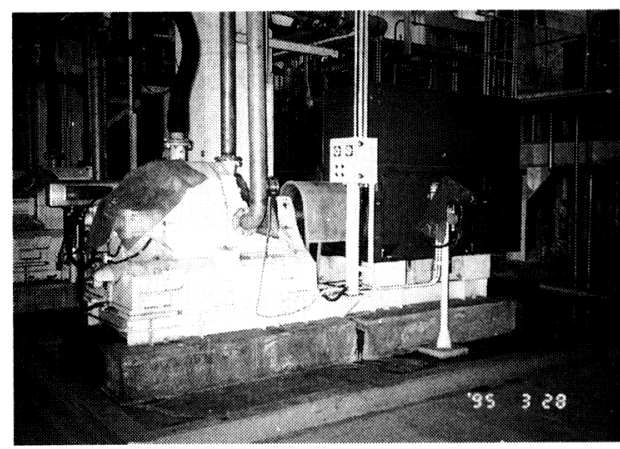

写真 2 レファイナー室

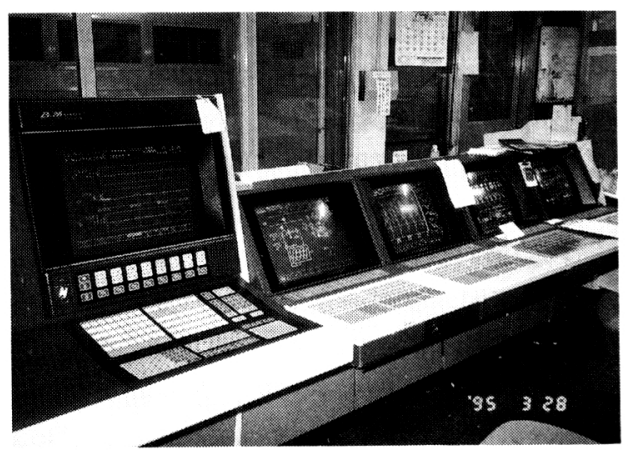

写真 3 抄紙部中央制御室

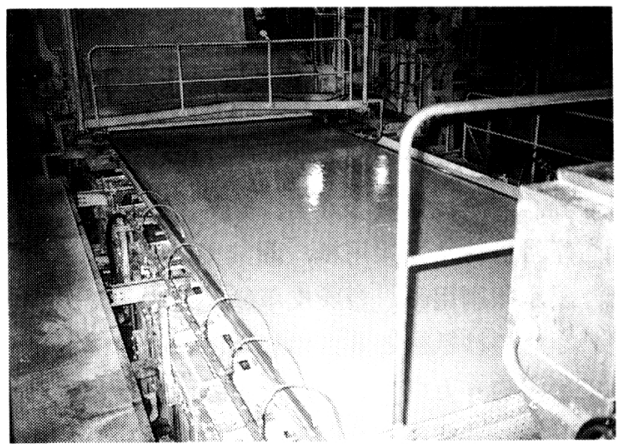

写真 413 号抄紙機

軸受部に設置した振動センサーにより，各部の振動值 を集積して遂次に周波数分析器により自動傾向管理を 行い，初期值よりある值以上になると警報がプリント アウトされるので，精密診断を行ってベアリングの交 換時期を決定している。その他潤滑油の自動管理を行 い，水分の入り易いパートでは分別しな沪過設備によ り連続的に除去したり，オイルミストの紙への飛散を 嫌って極端に油量を絞るパートには，個別油量制御警 報装置を設置する等，突発的なべアリング等の損傷に よる停止に対処している。製品の流れ及び幅方向の坪 量, 水分, 厚さ等の自動制御を始め, 異物対策として は工場建屋内をクラス 2 - 3の清浄度に維持可能に建 
表 2 三島工場抄紙機一覧表

\begin{tabular}{c|c|c|c|c|c}
\hline マシンNo. & 型 & $\begin{array}{c}\text { ワイヤー幅 } \\
(\mathrm{mm})\end{array}$ & $\begin{array}{c}\text { 平均 坪量 } \\
\left(\mathrm{g} / \mathrm{m}^{2}\right)\end{array}$ & $\begin{array}{c}\text { 日産 能力 } \\
(\mathrm{t} / \text { 日 })\end{array}$ & 運転開始年度 \\
\hline 1 & 長 網 多 筒 & 1,360 & 122 & 9.5 & $\mathrm{~S} 34$ \\
3 & 円 網 多 筒 & 1,320 & 157 & 5.8 & $\mathrm{~S} 28$ \\
7 & 長 網 多 筒 & 1,650 & 84 & 26.1 & $\mathrm{~S} 61$ \\
9 & 長 網 多 筒 & 1,575 & 800 & 21.4 & $\mathrm{~S} 41$ \\
10 & 円網ヤンキー & 953 & 100 & 1.5 & $\mathrm{~S} 36$ \\
11 & 長 網 多 筒 & 1,600 & 233 & 15.5 & $\mathrm{~S} 37$ \\
12 & 長 網 多 筒 & 1,650 & 80 & 19.1 & $\mathrm{~S} 37$ \\
13 & 長 網 多 筒 & 2,960 & 105 & 57.8 & $\mathrm{~S} 46$ \\
14 & 長 網 多 筒 & 3,000 & 105 & 89.7 & $\mathrm{~S} 62$ \\
\hline
\end{tabular}

屋空調器を設定して内圧をアップし，オイルミストや 結露を解消して，継ぎ目零のロール製品を提供してい る。

当工場の製品の一例としては OCR, OMR や MICR 等に代表される情報用紙や, 豊富な色と表情豊かな 2 千数百種類に及ぶファンシーペーパーや, 難燃不燃の 壁紙等に代表される工業用紙等があり，何れも当社の 長年に亘る伝統技術の積み重ねによるものである。一 般的に特殊紙の生産性は極好て低く自動化も容易では なかったが，ポープリールでの元枠ロールやスプール の交換，ワインダーやカッターへの搬送や空スプール の返送も自動化している。省エネルギーに就ても, 高 露点フード（露点温度 $65^{\circ} \mathrm{C}$ ）を設置し, 大容量の回 折式熱回収設備により, 大気への白煙の減少と蒸気消 費量の節減を行っている。ルーツブロワー排気は衝突, 回折等の消音溝を地下に設置して, 環境改善に努めて いる。

\section{3 加工部門及び仕上部門}

\section{(1) 加工部門}

現在 6 台の加工機とその他付属設備多数により多品 種小ロット生産を実施しているが，製品の多様化も目 まぐるしく, ライフサイクルも比較的短く, 商品開発 即生産の実験工場の延長線にあるが，多種類の薬剤の 搬入を始好調合設備も数千種類の処方に対処して自動 化している。その他, 加工部門では全自動スタッカー クレーンによる中間自動倉庫を設置しており，多階的 な搬出入口と連䌘して原反ロール，中間加工ロール， 製品と専用特殊パレットによりロール面を傷めない配 虑と多目的利用をしている。

\section{(2) 仕上部門 (写真 5，6)}

当工場では, 一部のメーカーの如く集中化した仕上 工場や，請負体制による運転方式はとらず，それぞれ

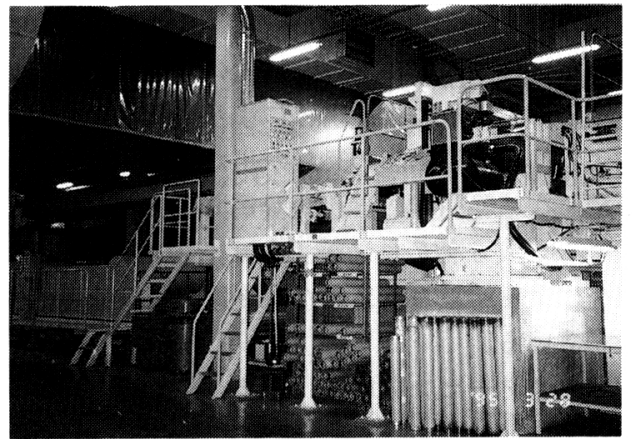

写真 5 全自動ツインドラムフルシンクロカッ 夕ー

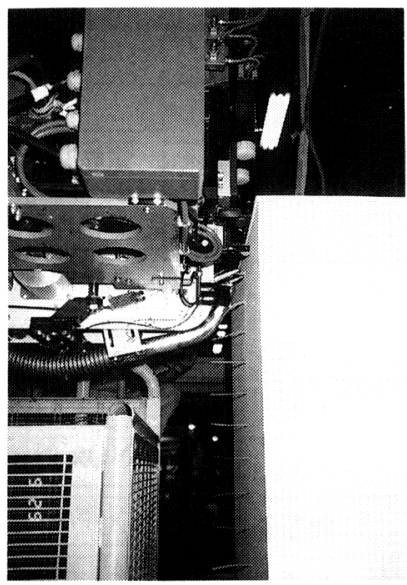

写真 6 全自動平判包装機の 自動りーム供給機

の抄紙部門や加工部門に直結した仕上工場と，当工場 の正規従業員による運転体制をとる事により，5千数 百種類に上る製品のマーケットインに到る品質保証の 責任を果たしている。ワインダーは紙管の供給やテー 
プ張りや, 久点検出装置と連繫した自動停止やスケジ ュール (スリッター幅，巻取り長さ，巻き硬さ，等) 管理，御しに到る迄全自動化し，全自動巻取包装機， ロール自動搬送機及び自動倉庫と製品搬出迄自動化ラ インとなっている。平判カッターは元枠ロールの自動 搬入から自動紙継ぎ，フルシンクロ 2 ロール電気式力 ッターが主体で, 久点検出装置と連繫した自動排紙や, 段替え時の専用パレット給排設備やフオーク設備と全 自動化し, 自動給紙装置付の全自動平判包装機とバー チカル自動ラベラ一等と一貫化した自動化ラインとな っている。

\section{4 動力部門 (写真 7)}

三島工場では昭和 60 年に第 1 発電所を建設し，当 初は自家発比率が約 $50 \%$ 強であったが，その後の抄 紙機増設で約 $30 \%$ になった事や，当地区が東京電力 (诛)の給電区域の西端にあり，地元に発電設備がない事 や夏季の落雷事故による瞬停により抄紙機の全停止と, 夫による排水の流出等の恐れが出たので，電力事業法 に抵触しない範囲で（自己消費電力の $200 \%$ 内），第 2 発電所を平成 6 年 7 月に竣工させ，現在では $100 \%$ の 自家発による給電と安定した余㮃電力を東京電力侏に 逆送している。

（1） ガスタービン発電機（表 3, 写真 8)
現在国内での最大生産機種で，技術的にも最高の燃 焼温度と夫に対処した冷却技術と保守技術を有する。 三菱 MF-111 B 型（定格ガス燃料で 17,500 kW）を 設置した。当面は灯油焚として煙色対策もあり蒸気噴

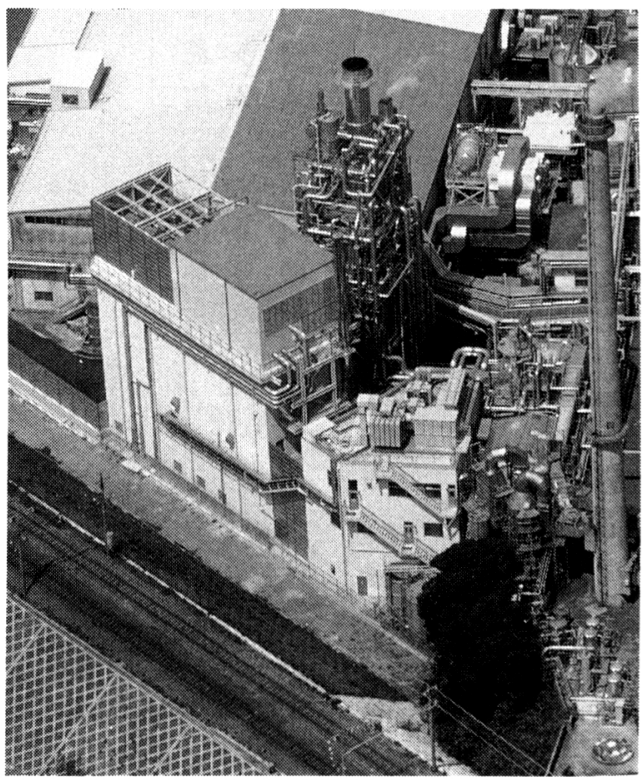

写真 7 第 2 発電所全景

表 3 ガスタービン発電設備一覽表

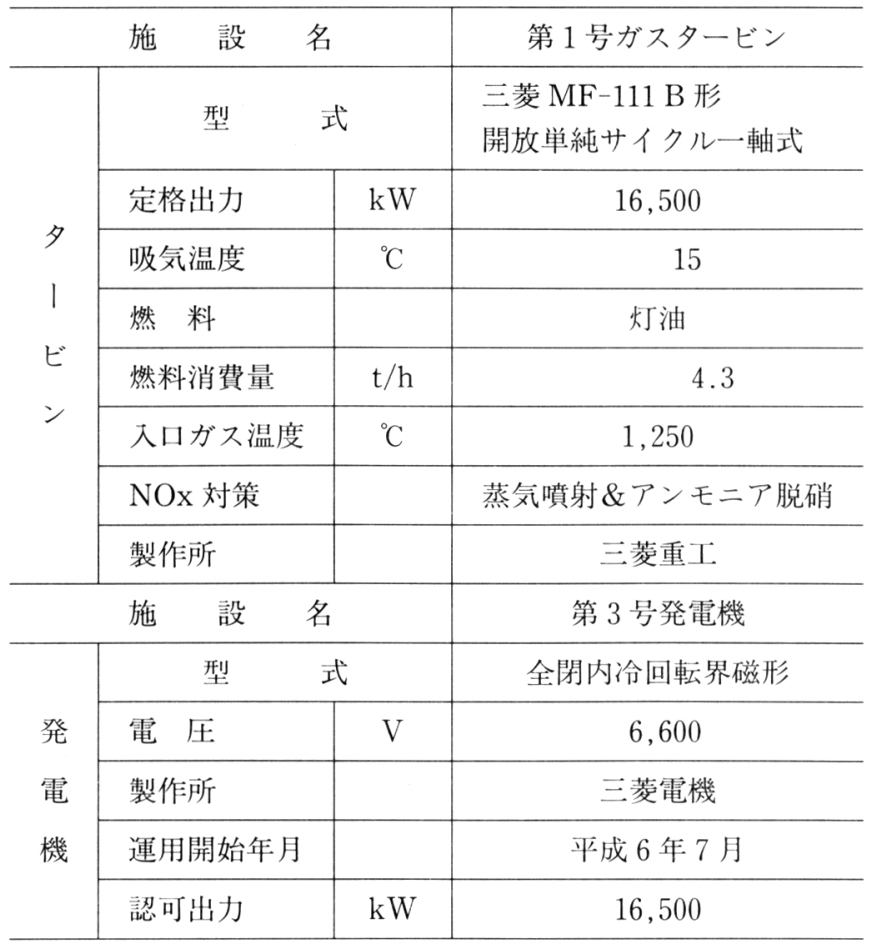




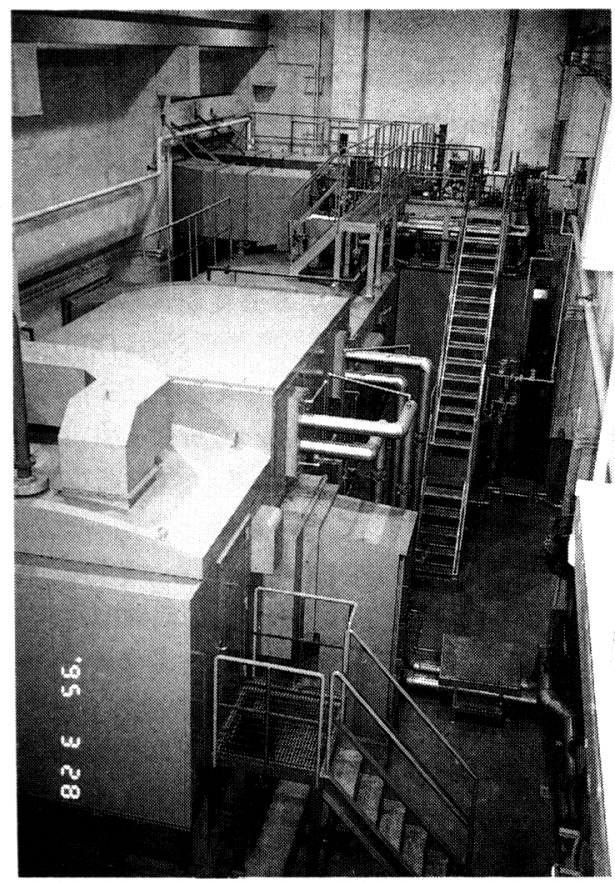

写真 8 ガスタービン発電機
射方式とし，定格 $16,500 \mathrm{~kW}$ としたが，将来 LNG 焚き水噴射方式として出力増加を可能として, 防爆仕 様等万全の仕様としている。環境対策と設置スペース を考虑し RC 造の多階構造とした建屋内の 2 階に設置 し, 消防法等の関係で更にインクロージャー (内部 $\mathrm{CO}_{2}$ 消火对象) 設置としたので, 敷地境界線の近傍 であるが遮音効果も充分であった。ガスタービン吸気 設備は粗, 中, 高性能 (1 $\mu$ 以下の海塩粒子も除去可 能） 3 段フイルターの密閉構造で, 建屋々上に隣接部 門よりのガスや降雨の吸引に対処し, 充分な滞留スぺ 一スと迂回した給気路を有するフイルター前室内に設 置したので, 雨水や霧の吸い込みによるフイルター沪 過抵抗の上昇もなく, 定修による停止時以外はコンプ レッサーの洗浄をやる必要がなかった。

(2) 蒸気夕ービン発電機（表 4)

2 台の蒸気タービンは何れも新日本造機㐺製で, 独 の AEG との技術提携による反動夕ービンで，一般の 衝動タービン翼に比し段数が 3 倍位多く, 軸径が太く て直に動翼を植え込む方式となっており翼車径が小さ く，ラビリンスからの漏洩蒸気量が少なく内部効率も

表 4 蒸気夕ービン発電設備一覧表

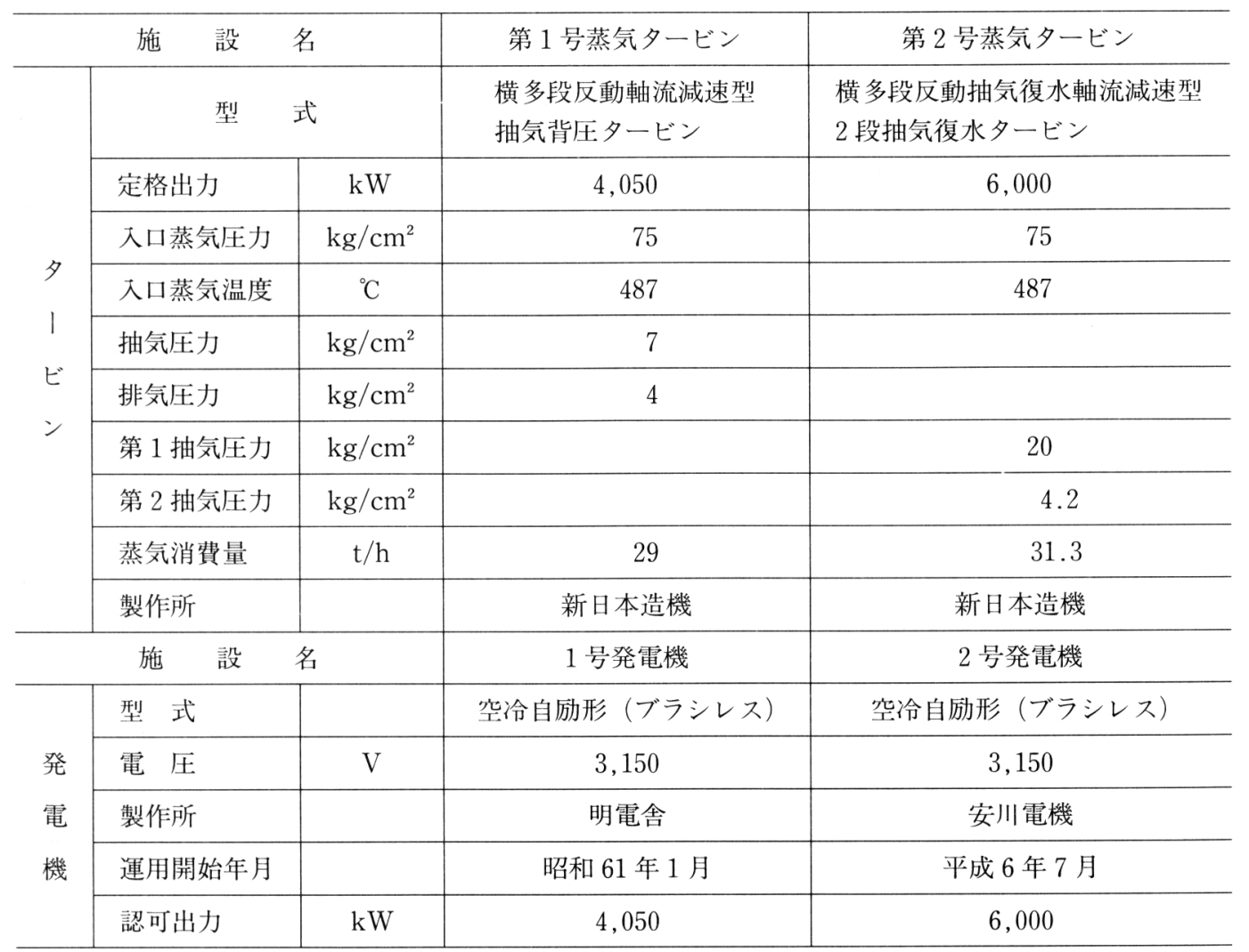


極めて高い。第 1 号蒸気夕ービンは当時の三島工場内 の蒸電比より最も発電単価の安い抽気背圧型とし, 第 2 号蒸気夕ービンは東京電力梸に安定した電力を逆送 する事と, 調成部門のバッチ吒解による電力負荷変動 と抄紙部門の多品種小ロット生産による電力と蒸気負 荷の跛行的変動に対処する為, ガスタービンへの蒸気 噴射用中圧蒸気の抽気も含めた 2 段抽気復水型とし, 前記ガスタービン発電機棟の下 1 階に設置し, 復水器 は建屋壁外に設置し，排気管は上向き型とした。復水 器の冷却水塔は白煙防止型とし, 特に冬季と雨季の白 煙を防止する如く循環水の入口高温部により給気を間 接加熱（防蝕材質使用）する事とし, 併せて大気への 排気温度を周囲温度近傍に低好如く循環水量を自動 制御する事により, 湿り空気線図での飽和線内におさ えて白煙を防止する如くした。

(3) ボイラー（表 5)

第 1 発電所用に当初設置した第 3 号ボイラーは, 当
時の第 1 号蒸気タービンへの給気量や蒸気体積比より 最大限の蒸気条件となった $77 \mathrm{~kg} / \mathrm{cm}^{2} \mathrm{G} \times 493^{\circ} \mathrm{C}$ とし たが, 当時でも此の規模の夕ービンとしては高い值で あったし，前述した翼車径の小さな AEG 方式でも限 界值に近かった。今回の第 2 発電所ではガスタービン の排熱ボイラーとして第 6 号ボイラーを設置したが, MF-111 B 形でもその排ガス温度が $570 \sim 510^{\circ} \mathrm{C} て ゙$, 前記の蒸気条件はきびしく, 特に蒸気噴射用の中圧蒸 気の第 2 号蒸気夕ービンでの抽気条件で限界に近く, $\mathrm{GT}$ 低負荷時は燃焼筒での失火の恐れもあった。第 6 号ボイラーは熱効率上低圧蒸気系も設置し, 蒸気バラ ンス及び環境対策上アフターバーニングも行はぬので, 排ガス温度は $140^{\circ} \mathrm{C}$ 内外となっている。その他定検時 用と蒸気負荷变動対策の一助として, ドラム容量の著 大な炉筒煙管式ボイラーをアキュムレーター兼用とし て第 7 号ボイラーとして，3 階建電気棟の 1 階に設置 した。

表 5 ボイラー設備一覧表

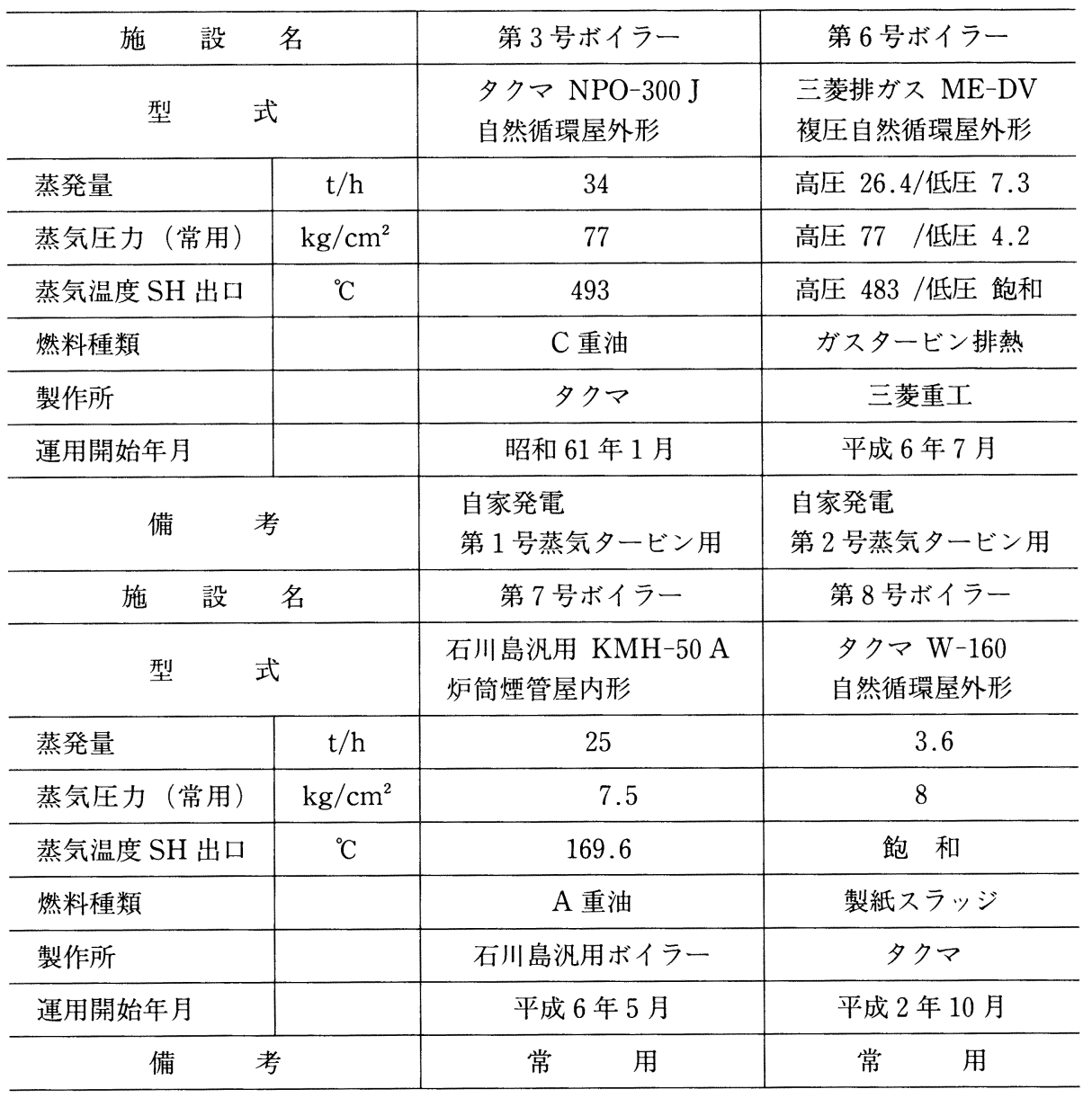


$\mathrm{C}$ 重油焚きボイラーには水酸化マグネシウムによる 排煙脱硫装置を設置し，エコノマイザーを経て供給さ れる $145^{\circ} \mathrm{C}$ 内外の排ガスで, 鉛熱交により $90^{\circ} \mathrm{C}$ 内外迄 給水を加熱すると共に, $70^{\circ} \mathrm{C}$ 内外の循環液でチ夕ン板 熱交による純水のメークアップ分（井水） $50^{\circ} \mathrm{C}$ 内 外迄加熱して, 発電所の熱効率の向上に寄与している。

（4）中央制御室（写真 9)

電気棟の 2 階は電気艋室で, 3 階は既設の第 1 発電 所の旧中央制御室と隣接して DCS 中央制御室を設置 した。旧第 1 発電所も含めて総合的なシステムとし, 買電々力監視画面, 買電々力パターン設定画面, 買 電々力カレンダー画面, 売電々力制御画面, 売電々力 パターン画面, 売電々カカレンダー画面, 売電当日パ ターン変更画面, 経済運転指標画面を完備している。 官庁検相日を除いた売電電力量をカレンダー画面によ り入力し, 昼夜間の時間帯により夫々ガスタービンの 出力設定を, 負荷変動には先ず 2 段抽気蒸気タービン が売電々力量制御を, 夫でカバー出来ぬ時は抽気背压 蒸気タービンとガスタービンが夫々追従制御する如く なっており, 安定した余㮃電力を東京電力侏に売電し ているが，三菱重工広島製作所のソフト構築に感謝す る。

\section{（5）受変電所（表 6)}

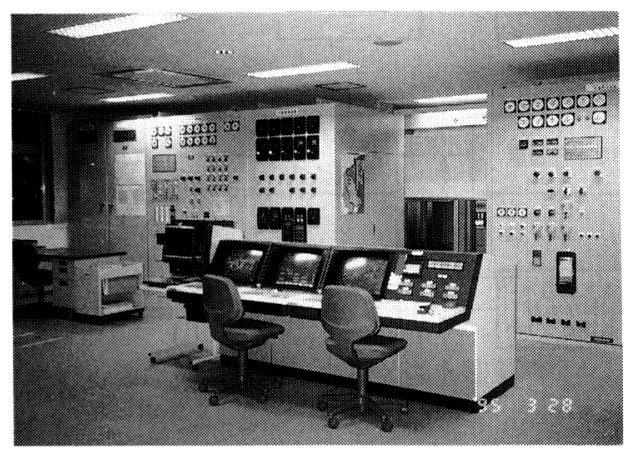

写真 9 動力中央制御室
$60 \mathrm{kV} 2$ 回線受電方式で, 常用回線と予備回線の無 停電切り替え可能な受電ループ切り替え装置と, 回線 事故時の受電自動切り替え装置を設置している。受電 用高圧器は 1 万 $\mathrm{kVA} \times 2$ 台で, 前記立体自動倉庫の 2 階に電気盤室とその屋上（地上 $20 \mathrm{~m}$ 高）に変電所 を設置している。

\section{5 環境改善 (表 7)}

長泉町との公害防止協定值は表 7 に示す如くである が，大正年間は周囲が全くの田園地帯であった当工場 も, 現在では住宅地も隣接し国道 1 号線からの貫い公 害 (夏場ディーゼルトラックの光化学オキシダント) もあるが, 地域の一員として脱硫脱硝消音, 排水処理, スラッジや産業廃棄物の焼却, 焼却灰の骨材化, 最終 処分場に到る迄, 総て自社の正規社員と社有ダンプト ラックで自己責任により完結する如く努力している。 放流水の測定值は公害防止協定值を遥かに下回り, BOD が 10 PPM 以下, SS が 2 PPM 以下となっいる が, 更に排水の再利用に就て研究を進めている。

（1）雨水浸透還元施設 (図 1，2，3，表 8, 写真 10) 図 1，2，3，表 8 に示す如く型幅 1520 型深 1780 の 大型 BOX カルバート側面に浸透用溝を設け, 道路や 緑地面の地下を先ずその表面に土粒痕を残す如く堀削 して埋設し, 浸透用溝面との間には砕石を入れて復旧 した。集水地域としては工場正面の高所地区約 0.5 ha を対象とし, 各建屋の雨樋と道路面の集水溝より, 落葉, ゴミ, 土砂の除去スクリーンを経て, 台風時等 の瞬間雨量等の貯留 (約 $350 \mathrm{~m}^{3}$ 容量) も兼㸚て BOX 内に流入させる如くした。好天時には BOX 内の貯水 が砕石と土粒痕を経て地下水に還元され，貯水量は 0 となるので, 界面に発生するスライム等も, 土中の各 種菌類により掃除され年間を通じ目詰り等が防止され る。

\section{（2）用 水}

前述した如く当地は富士山の溶岩流の末端に近く, 工場より $1.5 \mathrm{~km}$ の柿田川では現在も 102 万 $\mathrm{m}^{3} /$ 日の

表 6 受変電設備一覧表

\begin{tabular}{|c|c|c|c|c|}
\hline 施 設 & 番 号 & No. 1 & No. 2 & No. 3 \\
\hline 型 & 式 & $\begin{array}{l}\text { 屋外用 } \\
\text { 油入自冷式 }\end{array}$ & $\begin{array}{l}\text { 屋外用 } \\
\text { 油入自冷式 }\end{array}$ & $\begin{array}{l}\text { 屋外用 } \\
\text { 油入自冷式 }\end{array}$ \\
\hline 定格容量 & $\mathrm{kVA}$ & 10,000 & 10,000 & 20,000 \\
\hline 定格電圧 & $\mathrm{kV}$ & $63 / 3.15$ & $63 / 3.15$ & $63 / 3.15$ \\
\hline 電 流 & A & $91.6 / 1,830$ & $91.6 / 1,830$ & $183 / 1,750$ \\
\hline 製作所 & & 明電舎 & 明電舎 & 明電舎 \\
\hline
\end{tabular}




工 場 紹 介

表 7 長泉町との公害防止協定値

\begin{tabular}{|c|c|c|c|c|}
\hline \multicolumn{4}{|c|}{ 項 } & 公害防止協定値 \\
\hline $\begin{array}{l}\text { 水質污濁 } \\
\text { (日間平均) }\end{array}$ & $\begin{array}{l}\mathrm{PH} \\
\mathrm{BOD} \\
\mathrm{S} \mathrm{S}\end{array}$ & \multicolumn{2}{|c|}{ 放流水量 1 万 5 万 $\mathrm{m}^{3} /$ 日 } & $\begin{array}{l}6.0 \sim 8.4 \\
30 \mathrm{ppm} \text { 以下 } \\
45 \mathrm{ppm} \text { 以下 }\end{array}$ \\
\hline \multirow{8}{*}{ 大気污染 } & \multicolumn{3}{|c|}{ 硫黄酸化物（K 值） } & 9.0 以下 \\
\hline & \multicolumn{3}{|c|}{ 燃料中硫黄分 } & $1.0 \%$ 以下 \\
\hline & \multirow{3}{*}{ ばいじん } & 液体燃焼ボイラー & $\begin{array}{l}1 \text { 万 } \mathrm{Nm}^{3} / \mathrm{h} \text { 未満 } \\
1 \text { 万 } \mathrm{Nm}^{3} / \mathrm{h} \text { 以上 }\end{array}$ & $\begin{array}{l}0.270 \mathrm{~g} / \mathrm{Nm}^{3} \text { 以下 } \\
0.230 \mathrm{~g} / \mathrm{Nm}^{3} \text { 以下 }\end{array}$ \\
\hline & & 廃棄物焼却炉 & 4 万 $\mathrm{Nm}^{3} / \mathrm{h}$ 未満 & $0.450 \mathrm{~g} / \mathrm{Nm}^{3}$ 以下 \\
\hline & & \multicolumn{2}{|l|}{ ガスタービン } & $0.045 \mathrm{~g} / \mathrm{Nm}^{3}$ 以下 \\
\hline & \multirow{3}{*}{ 窒素酸化物 } & 液体燃焼ボイラー & $\begin{array}{l}1 \text { 万 } \mathrm{Nm}^{3} / \mathrm{h} \text { 未満 } \\
1 \text { 万 } \mathrm{Nm}^{3} / \mathrm{h} \text { 以上 }\end{array}$ & $\begin{array}{l}175 \mathrm{ppm} \text { 以下 } \\
220 \mathrm{ppm} \text { 以下 }\end{array}$ \\
\hline & & 廃棄物焼却炉 & 4 万 $\mathrm{Nm}^{3} / \mathrm{h}$ 末満 & $240 \mathrm{ppm}$ 以下 \\
\hline & & ガスタービン & 4.5 万 $\mathrm{Nm}^{3} / \mathrm{h}$ 以上 & $65 \mathrm{ppm}$ 以下 \\
\hline $\begin{array}{c}\text { 騒 音 } \\
\text { (敷地境界) }\end{array}$ & & & $\begin{array}{ll}\text { 朝 } & \text { 夕 } \\
\text { 昼 } & \text { 間 } \\
\text { 夜 } & \text { 間 }\end{array}$ & $\begin{array}{l}63 \text { ホン以下 } \\
68 \text { ホン以下 } \\
58 \text { ホン以下 }\end{array}$ \\
\hline
\end{tabular}

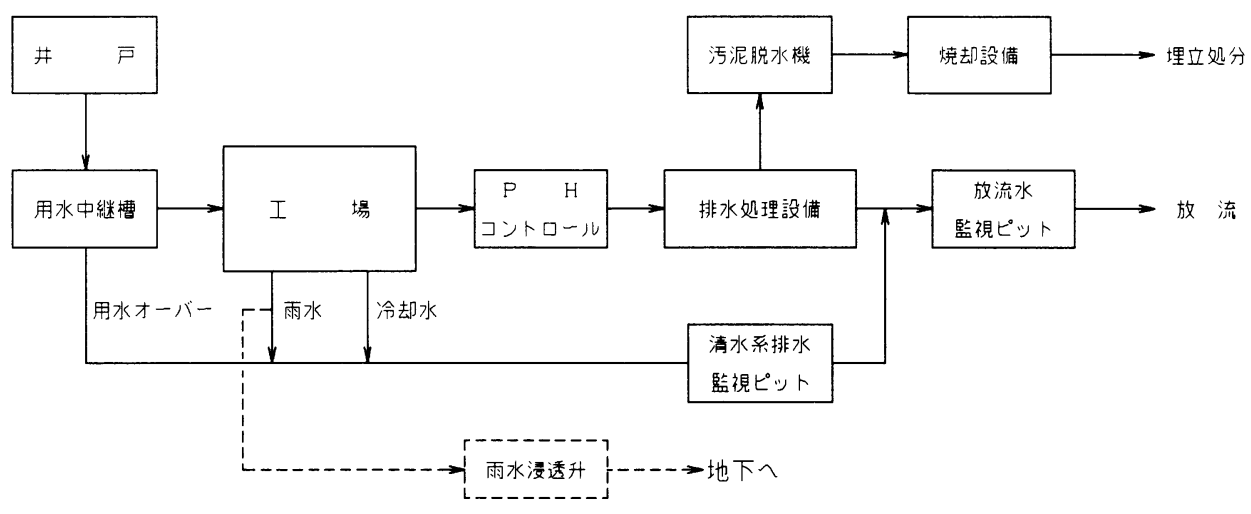

図 1 工場雨水，用排水フロー
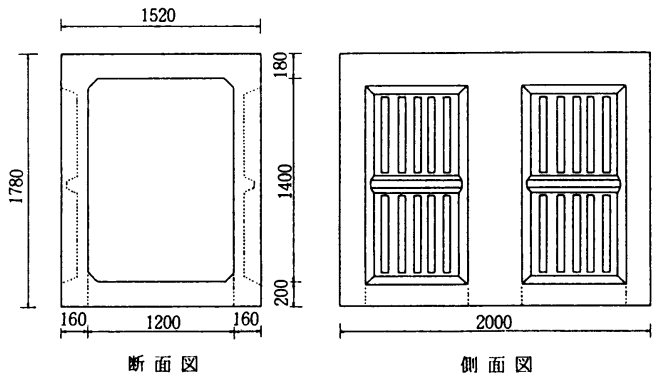

図 2 雨水浸透還元設備構造
涌水があるが, 北部地域の御殿場, 裙野地区での住宅 や工業団地開発も目覚ましく, 之等上流地域での急速 な地下水汲み上げ量の増加が問題化している。従って 工場内の雨水の地下への浸透還元や, 排水の再利用等 にも注力しており，溶岩層やその他地層を経た $15^{\circ} \mathrm{C}$. の井水をサンドセパレーター付受水槽より, 先ず建屋 空調器の冷却水に使用し, 昇温した排水を高架水槽に 揚水して, チューブフィルターにより沪過後, ボイラ 一系の純水製造や製紙用に利用している。

(3) 排水処理施設（図 4) 
表 8

\begin{tabular}{|c|c|c|c|}
\hline 番号 & 項 目 & 諸 & \\
\hline 1 & 面 積 & 0.499659 ha & \\
\hline 2 & 流 出 係 数 & $\mathrm{f}=0.9$ & 密集市街地 \\
\hline 3 & 降雨継続時間 & $\mathrm{ti}=60$ 分 & \\
\hline 4 & 降 雨 強 度 & $\mathrm{ri}=75 \mathrm{~mm} / \mathrm{hr}$ & \\
\hline 5 & 浸 透 係 数 & $\mathrm{K}=1.74 \times 10^{-2}(\mathrm{~cm} / \mathrm{s})$ & 関東ローム \\
\hline 6 & 下流への放流 & 0 & \\
\hline 7 & 浸 透 施 設 & ボックス式浸透管 内径 $1,200 \times 1,400$ & \\
\hline 8 & 流 出 量 & $1 / 360 \times 0.9 \times 0.5 \times 75=0.0937 \mathrm{~m}^{3} / \mathrm{s}$ & $5.62 \mathrm{~m} /$ 分 \\
\hline 9 & 浸 透 面 積 & $1 \mathrm{~m}$ 当たり $1.98 \times 2=3.96 \mathrm{~m}^{2}$ & \\
\hline 10 & 浸透施設延長 & $106 \mathrm{~m}$ & \\
\hline 11 & 貯留浸透量 & $5.62 \mathrm{~m}^{3} /$ 分 $\div 106 \mathrm{~m} \times 3.96 \mathrm{~m}^{2}=13.4 \mathrm{l} /$ 分 & \\
\hline 12 & 単位浸透量 & $1 \mathrm{~m}$ 当たり $13.4 \mathrm{l} /$ 分 $\times 20 \%=2.68 \mathrm{l} /$ 分 & \\
\hline
\end{tabular}

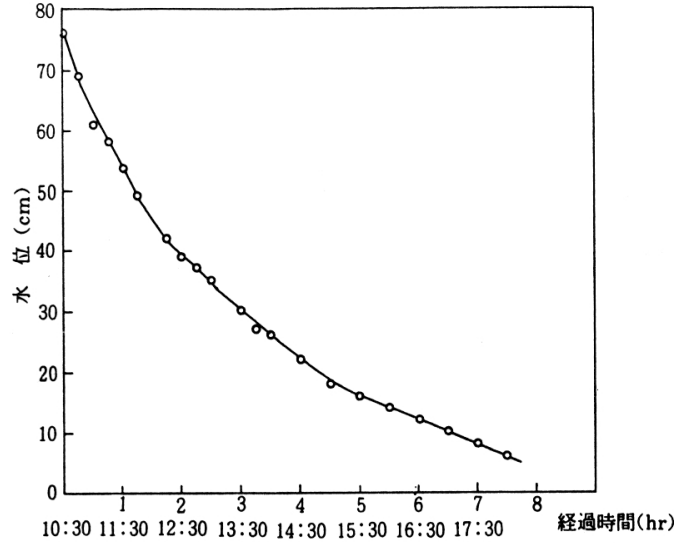

図 3 雨水浸透水量テスト結果

工場の排水は各抄紙機や加工機, 動力部門等で, 夫々循環使用されて，その最終排水が図 4 に示す如く， $\mathrm{pH}$ 処理後に凝集沈澱槽 2 基に入り, 殆ど無色透明の 処理水が黄瀬川に放流されるが, 各発生源より放流点 迄多数の $\mathrm{pH}$ 計, 濁度計, 流量計により常時連続测定 （定期的に分析担当者が検定）して，中央制御室でコ ンピューターにより管理している。東電側で不足の事 故により停電した時でも, 瞬時に自家発による単独運 転に切り替わり，排水処理の完璧を期している。

\section{(4) スラッジ処理施設}

凝集沈澱した污染はスクリュープレスにより約 $58 \%$ 水分に脱水してサイロに貯留する。一方損紙に就

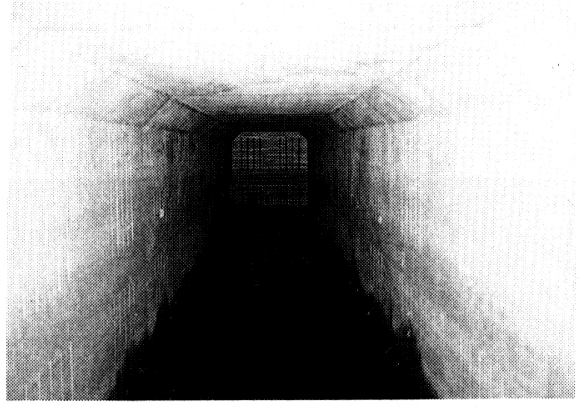

写真 10 雨水浸透還元設備

ては再利用可能な抄き出し損紙等は各抄紙機のブロー クラインで再使用すると共に，パルプベールやクリー ナーリジェクトの污れ原料は, 特別精選後に再使用す る。その他再使用不可能な耐水性が高い損紙は, 特殊 大型破砕機で細片に破砕して別のサイロに貯留し，前 記排水スラッジと夫々定量に混合して流動床式焼却炉 （表 5 の第 8 号ボイラー）で焼却し，低圧蒸気を回収 している。全設備の運転は自動化しており, 中央制御 室より管理している。

（5）人工骨材施設と最終処理施設（写真 11，12） 環境改善事業の一端として，流動床式烤却炉の焼却 灰を人工骨材として活用する事を計画し，長泉工業団 地に工場を建設した。焼却灰にセメントと特殊固化剂 を添加し，加圧混和機で固化後破砕して出荷している。 用途は路盘材や各種の型材（歩道用インターロッキン グやブロック等々) で, 軽量で且は修正 CBR 值が 


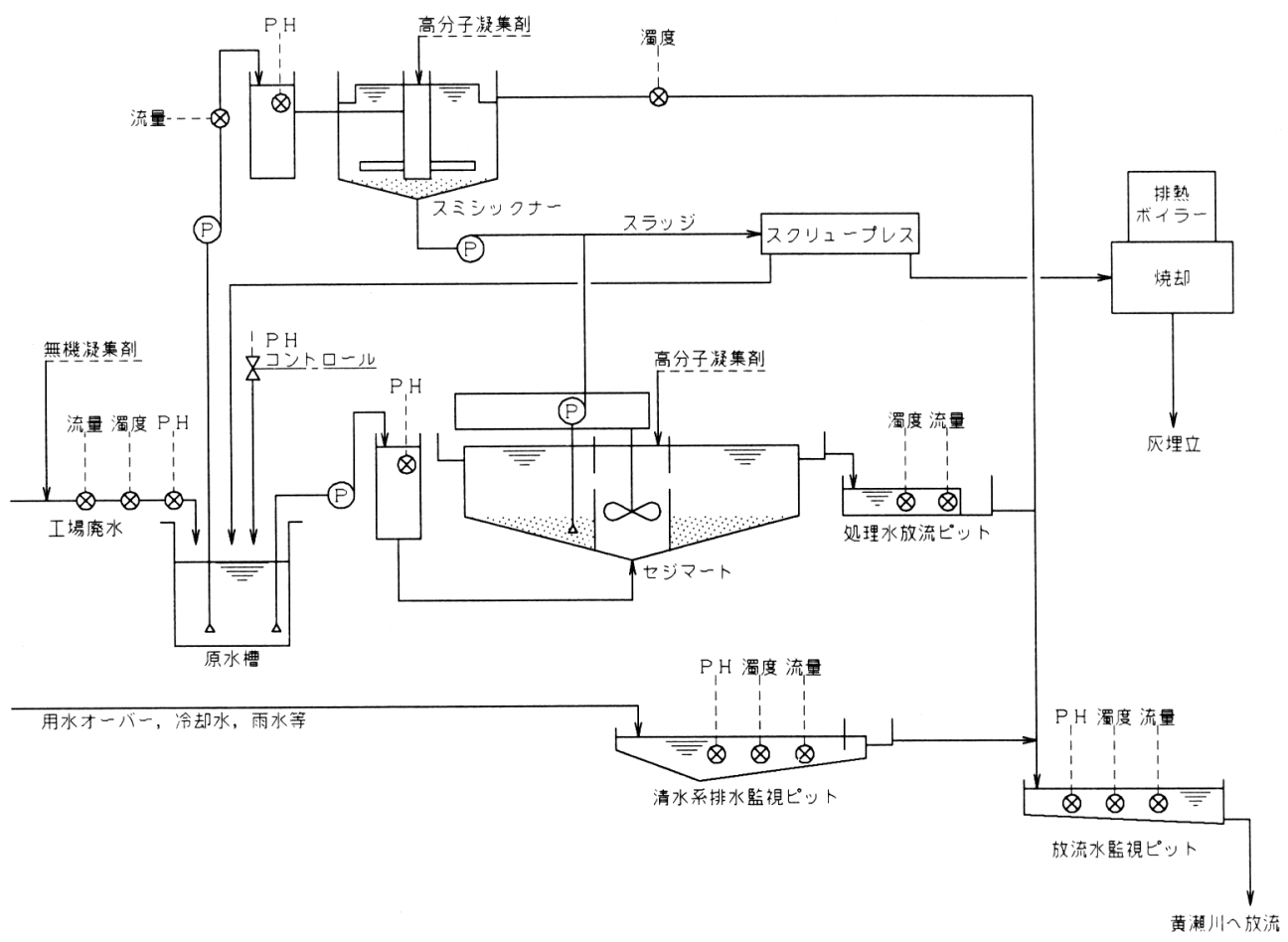

図 4 排水処理フロー

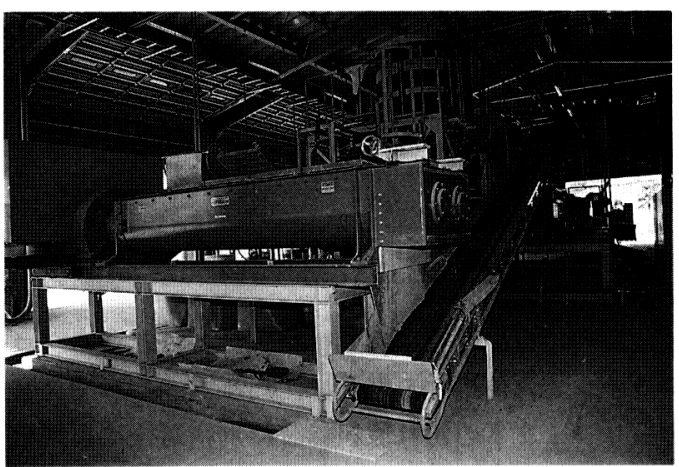

写真 11 人工骨材工場

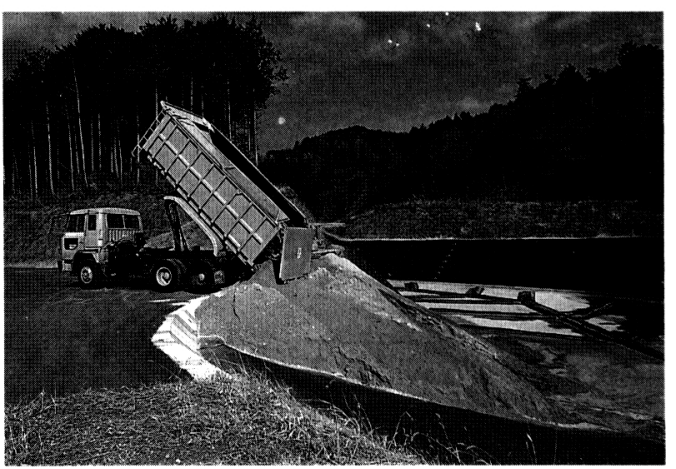

写真 12 最終処理設備

\section{4. むすび}

以上設備を中心に当工場の概要を紹介させて頂いた が，今後ますます多様化，高度化してくる市場のニー ズを先取りして, 首都圈より 60 分の地の利をいかし, 先行した研究開発態勢と適切で果断な先行投資により, 地域，ユーザーと共に未来を開拓すべく全社一丸とな り精進しているので, 今後共よろしく御支罟を頂きた い。 


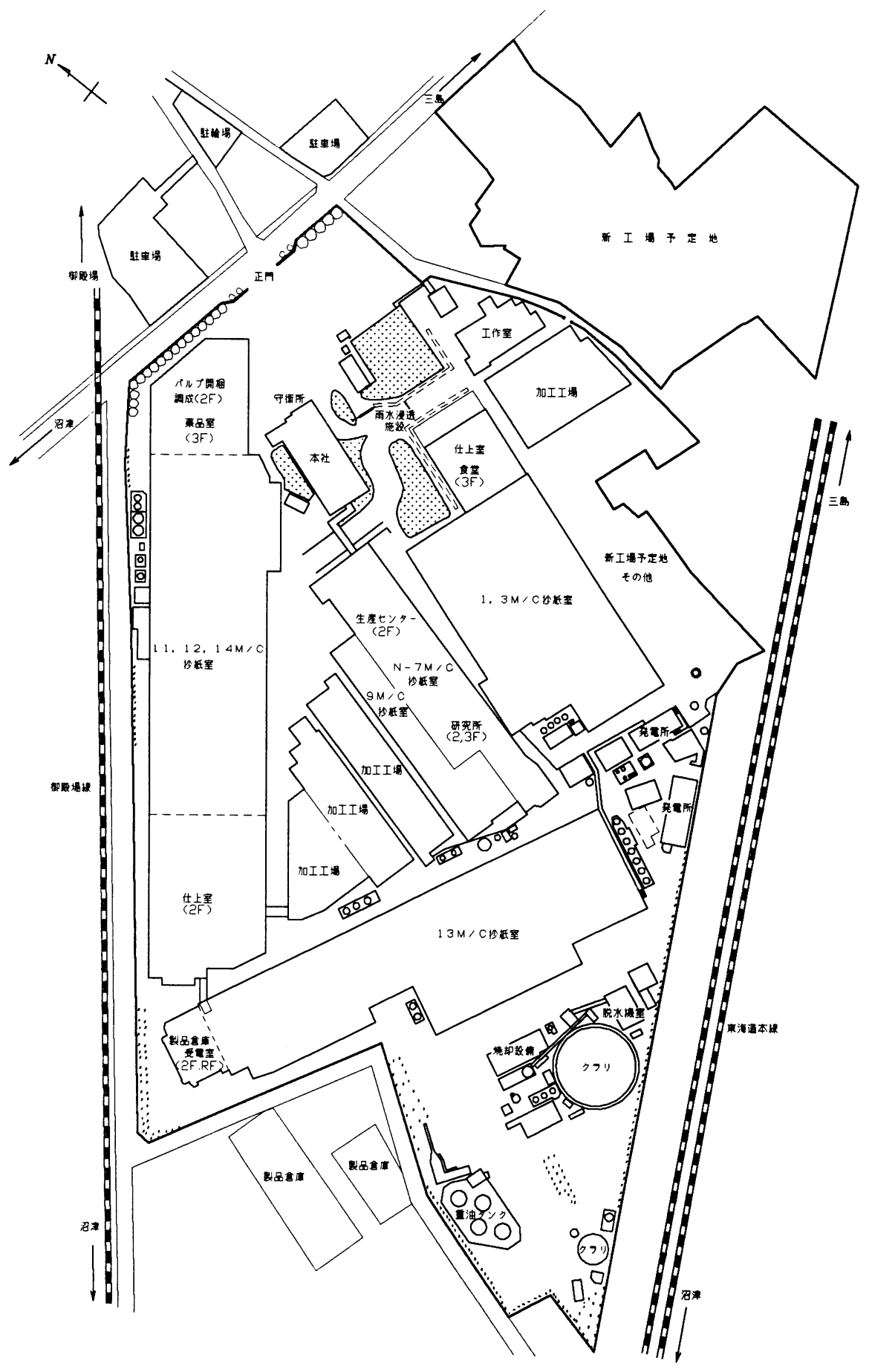

本社三島工場建物配置図 